\title{
Effect of alpha amylase on early childhood caries: a matched case-control study
}

\author{
Efeito da alfa-amilase na cárie precoce da infância: estudo caso-controle \\ Farzad MOJARAD (DDS) ${ }^{1}$, Samira FAZLOLLAHIFAR (DMD) ${ }^{1}$, Jalal POOROLAJAL (MD, PhD) ${ }^{2}$, Mehrdad HAJILOOI (PhD) ${ }^{3}$ \\ 1 - Department of Pediatric Dentistry, School of Dentistry, Hamadan University of Medical Sciences, Hamadan, Iran \\ 2 - Research Center for Health Sciences, Department of Epidemiology \& Biostatistics, School of Public Health, Hamadan University of \\ Medical Sciences, Hamadan, Iran \\ 3 - Department of Pathology, School of Dentistry, Hamadan University of Medical Sciences, Hamadan, Iran
}

\section{ABSTRACT}

Objective: This study was implemented in order to investigate the effect of salivary alpha-amylase level on early childhood caries (ECC). Methods: In this matched case-control study, which was carried out from November 2011 to March 2012 in Hamadan City, the west of Iran, mean levels of salivary alpha-amylase of 84 ECC-active cases were compared to that of 84 ECCfree controls using spectrophotometric method to assay enzyme kinetics. The two groups were matched by oral hygiene (frequency of tooth brushing per day) and food habits (frequency of sugar consumption between servings). Subsequently, a subsample of 28 cases was undergone emergency treatment of dental caries. Alpha amylase level was measured before treatment and 30 to 45 min later. Results: The results indicated an inverse relationship between alpha-amylase level and dental caries. The mean level of salivary alpha-amylase was 28.27 and $42.08 \mathrm{kU} / \mathrm{L}$ in cases and controls respectively $(P=0.001)$. In addition, emergency treatment of dental caries increased the level of salivary alphaamylase significantly from $15.05 \mathrm{kU} / \mathrm{L}$ before treatment to $23.94 \mathrm{kU} / \mathrm{L}$ thereafter $(\mathrm{P}=0.001)$ although the level of alpha-amylase did not reach the normal level of ECC-free controls. Conclusion: Generally it can be concluded that low levels of alpha-amylase may promote early childhood caries. On the other hand, dental caries may subsequently reduce the level of salivary alpha-amylase. This vicious cycle may promote and then accelerate caries formation among susceptible people with low level of salivary alpha-amylase.

\section{RESUMO}

Objetivo: Este estudo foi implementado para investigar o efeito do nível de alfa-amilase salivar sobre a cárie precoce da infância (CPI). Métodos: Neste estudo de caso-controle pareado conduzido entre novembro de 2011 e março de 2012, na cidade de Hamadan - oeste do Irã, os níveis médios da alfa-amilase salivar de 84 pacientes apresentando CPI ativa foram comparados ao níveis de 84 pacientes-controle, livres de CPI, utilizandose método espectrométrico para analisar a cinética enzimática. Os dois grupos foram agrupados de acordo com a higiene oral (frequência de escovação dentária diária) e hábitos de dieta (frequência de consumo de açúcar entre refeições). Posteriormente, uma parcela da amostra, composta de 28 casos, foi submetida ao tratamento de urgência da cárie dentária. O nível de alfaamilase foi mensurada antes do tratamento e após 30 a 45 minutos. Resultados: Os resultados mostraram relação inversa entre o nível de alfa-amilase e cárie dentária. $\mathrm{O}$ nível médio de amilase salivar foi de 28,27 e 42,08 kU/L para os grupos teste e controle, respectivamente $(\mathrm{P}=$ 0,001). Adicionalmente, o tratamento de urgência da cárie dentária resultou em aumento significativamente dos níveis de alfa-amilase salivar, de 15,05 kU/L antes do tratamento para 23,94 kU/L após o tratamento ( $\mathrm{P}$ $=0,001$ ), embora os níveis de alfa-amilase salivar não tenham atingido os níveis normais apresentados pelos controles livres de CPI. Conclusão: Conclui-se que os baixos níveis de alfa-amilase podem produzir a cárie precoce da infância. Por outro lado, a cárie dentária deve reduzir subsequentemente os níveis de alfa-amilase salivar. Este ciclo vicioso deve promover e acelerar a formação de lesões cariosas em pessoas susceptíveis com baixo nível de alfa-amilase salivar.

\section{KEYWORDS}

Alpha-amylases; Dental caries; Case-Control Studies; Iran.

\section{PALAVRAS-CHAVE}

Alfa-amilase; Cárie dentária; Estudo de casocontrole; Irã. 


\section{INTRODUCTION}

$\mathrm{E}$ arly Childhood Caries (ECC) is a disease characterized by severe decay in the teeth of infants or young children, typically under the age of 6 [1]. ECC is an infectious and transmissible, but preventable disease which is initiated by the bacterium Streptococus mutans [2]. Despite the major advances in the field of caries prevention over the past few decades, ECC is the most common chronic childhood disease [1-3].

ECC manifests frequently as tooth pain and infection especially among low-income children who have limited access to dental services [4]. ECC can predispose children to significant oral and systemic problems such as eating difficulties, altered speech, poor body image, and low selfesteem [2].

ECC is a multifactorial disease associated with social, psychological, and behavioral mediating factors [5-7] such as low-frequent or improper tooth brushing [8] underweight [9] malnutrition [10], poor oral hygiene [2], inappropriate feeding patterns [11], high carbohydrate consumption [12], and transmission of infectious microorganisms through mothers' or caregivers' saliva during nurturing activities [2].

In addition to well-known mentioned risk factors of ECC, some previous observational studies have suggested a significant relationship between alpha-amylase, dental plaque and caries formation [13-15]. However, results from other studies are inconsistent and do not support correlation between dental caries and salivary amylase activity $[6,16]$. Therefore, the present case-control study was conducted to address the interrelation between level of alpha-amylase and ECC.

\section{MATERIAL AND METHODS}

Local Human Subject Review Board of Hamadan University of Medical Sciences approved this study. The objectives of the study were explained for the children's parents and they signed the informed consent. In this matched case-control study, which was carried out from November 2011 to March 2012 in Hamadan City, Western Iran, 168 children 3-6 years of age participated including 84 ECC-active children as case groups and 68 ECC-free children as control groups.
A previously published study [6] had estimated that the mean level of alpha-amylase was $71.8 \mathrm{U} / \mathrm{L}(\mathrm{SD}=48.6)$ in ECC-free children and $122.8 \mathrm{U} / \mathrm{L}(\mathrm{SD}=101.5)$ in ECC-active children. Accordingly, we needed 84 casecontrol sets (one case to one control) with a 0.01 significance level and 95\% statistical power.

The exposure of interest was the level of salivary alpha-amylase. The levels of alphaamylase of the two groups were measured and compared. Only children without congenital or systemic disease and without history of dental intervention were enrolled in the study.

The children were evaluated regarding decay-missing-filling surface (dmfs) index. The children with dental carries on at least one surface and utmost 20 surfaces were considered as cases. The caries free children were considered as controls. The controls were individually matched to the cases by oral hygiene (frequency of tooth brushing per day) and food habits (frequency of sugar consumption between servings). From three dmfs indices, only dental decay (but not missing or filling) was used for classification of the children because participants had no history of dentistry intervention. In addition, children with dental caries on utmost 20 surfaces were enrolled in the case groups because it might be possible that dental caries had the most effect on salivary level. The data were collected using a predesigned questionnaire, which was composed of two parts. The first part included the children's general characteristics such as age, sex, weight, height, oral hygiene and food habits. The second part included the results of exploring dmfs index. For this purpose, we asked the parents to prohibit the children from eating and drinking one hour before oral examination. Before exploring $\mathrm{dmfs}$ index, we cleaned the teeth surface with a piece of sterile gaze. Then, we explored dmfs index using dental explorers, sound and artificial light.

After oral examination, we collected $3 \mathrm{ml}$ non-stimulated salivary using spiting way. Hence, we asked the children to sit on a chair and lean forward dropping down their head. Since the level of salivary may vary during the day, we collected all saliva samples between 8 to $11 \mathrm{am}$. Sampling time took about $20 \mathrm{~min}$. Saliva samples were kept at a temperature of $4^{\circ} \mathrm{C}$ and were transferred to the laboratory at the end of each day. In the 
laboratory, saliva was centrifuged and the resulted solutions were kept at a temperature of $-20^{\circ} \mathrm{C}$ for final measurement of alpha amylase level. The level of salivary alpha-amylase was measured by testing spectrophotometric method to assay enzyme kinetics made by Pars-Azmoon kit, Iran and reported in term of kilo unit per liter $(\mathrm{kU} / \mathrm{L})$.

Additionally, in order to assess the relationship between dmfs index and salivary alpha-amylase level, a subsample of 28 cases underwent emergency treatment of dental caries. Then 30 to 45 min later another saliva sample was collected in the same way.

Paired t-test was used to compare the mean level of salivary alpha-amylase between the two groups. Chi-squared test was used to investigate the association between nominal variables. All analysis were performed at the 95\% significance level $(\mathrm{P}<0.05)$ using statistical software Stata 11 (StataCorp, College Station, TX, USA).

\section{RESULTS}

In this study, 84 ECC-active cases were compared with 84 ECC-free controls. The distributions of the general characteristics of the cases and controls are shown in Table 1. Sex and age distributions of the two groups as well as the educational levels of their parents were almost the same with no statistically significant difference. Although mean difference of body mass index (BMI) between the two groups was statistically significant but did not seem clinically important.

The mean level of salivary alphaamylase in the cases and control groups and in subsample of cases before and after dental caries treatment are shown and compared in Table 2. The mean level of salivary alphaamylase in the control groups was higher than that of case groups; $42.08 \mathrm{kU} / \mathrm{L}$ versus 28.37 $\mathrm{kU} / \mathrm{L}$ respectively and the difference between the means was statistically significant $(\mathrm{P}=0.001$

Emergency treatment of dental caries increased the level of salivary alpha-amylase significantly from $15.05 \mathrm{kU} / \mathrm{L}$ before treatment to $23.94 \mathrm{kU} / \mathrm{L}$ thereafter $(\mathrm{P}=0.001)$ although the level of alpha-amylase did not reach the normal level of ECC-free controls (Table 2).
Table 1 - Distribution of the general characteristics of the cases and controls

\begin{tabular}{|c|c|c|c|}
\hline & $\begin{array}{l}\text { Controls } \\
\mathrm{N}=84\end{array}$ & $\begin{array}{l}\text { Cases } \\
\mathrm{N}=84\end{array}$ & Pvalue \\
\hline Sex & & & 0.877 \\
\hline Male & 43 & 42 & \\
\hline Female & 41 & 42 & \\
\hline Mean age (year) & 3.92 & 4.00 & 0.509 \\
\hline Body Mass Index & 15.40 & 16.06 & 0.017 \\
\hline Oral Hygiene (tooth brush per/day) & & & $1.000^{\mathrm{a}}$ \\
\hline Once & 18 & 18 & \\
\hline Twice & 40 & 40 & \\
\hline Irregular & 26 & 26 & \\
\hline $\begin{array}{l}\text { Using sugar between meals } \\
\text { (serving/day) }\end{array}$ & & & $1.000^{\mathrm{a}}$ \\
\hline Once & 7 & 7 & \\
\hline Twice & 39 & 39 & \\
\hline Thrice & 38 & 38 & \\
\hline Mother education & & & 0.049 \\
\hline High school & 11 & 21 & \\
\hline Academic & 73 & 63 & \\
\hline Father education & & & 0.078 \\
\hline High school & 8 & 16 & \\
\hline Academic & 76 & 68 & \\
\hline
\end{tabular}

${ }^{a}$ Matched variable

Table 2 - Mean level of salivary a-amylase among cases and controls using paired t-test to compared mean difference between the two groups.

\begin{tabular}{|cccccc|}
\hline & \multicolumn{4}{c}{ Salivary $\boldsymbol{\alpha}$-amylase (kU/L) } & Paired \\
\hline Group & Number & Mean & SE & SD & t-test \\
\hline Controls (baseline) & 84 & 42.08 & 2.97 & 27.25 & 0.001 \\
\hline Cases (baseline) & 84 & 28.37 & 2.37 & 21.73 & \\
\hline Difference & 84 & 13.71 & 3.78 & 34.67 & \\
Cases (before treatment) & 28 & 15.05 & 1.13 & 5.97 & 0.001 \\
\hline Cases (after treatment) & 28 & 23.94 & 2.41 & 12.73 & \\
\hline Difference & 28 & 8.89 & 1.44 & 7.61 & \\
\hline Twice & 40 & 40 & & & \\
\hline Irregular & 26 & 26 & & & \\
\hline
\end{tabular}

\section{DISCUSSION}

Alpha-amylase is one of the major components of saliva [17]. It is a calcium-dependent metalloenzyme which can hydrolyze starch to glucose and maltose;consequently, having an important role in binding to bacteria $[18,19]$. 
On the other hand, ECC is a multifactorial disease associated with several social, psychological, and behavioral mediating factors [5-7]. Our results revealed a significant but inverse correlation between salivary alpha-amylase level and ECC. In this study, ECC-active cases and ECC-free controls were matched for effective confounding variables such as oral hygiene and food habits. Furthermore, the general characteristics of the two groups were nearly the same such as sex, gender and parents' education level. Therefore, we might be able to suggest a real correlation between salivary alpha-amylase and ECC.

In this study, we assessed the relationship between salivary alpha-amylase and ECC while there are at least 50 macromolecular components in saliva, such as IgA and IgG which play an important role in colonization and metabolism of the oral bacteria [6]. Perhaps, some of these components may have either synergistic or antagonistic effects on salivary alpha-amylase activity and thus, may strengthen or weaken the link between alpha-amylase and ECC.

We assessed the effect of emergency treatment of dental caries on salivary alphaamylase level. The results showed that the emergency treatment of dental caries in a subsample of children (28 ECC-active cases) increased significantly the mean level of salivary alpha-amylase compared to before treatment. However, the level of alpha amylase did not reach that of ECC-free children. This issue indicates that caries-active children may have inherently lower levels of salivary alphaamylase, which is making them susceptible to dental caries although dental caries may subsequently exacerbate the reduction in salivary alpha-amylase level.

A few studies addressed the relationship between salivary alpha-amylase and dental caries but the results are inconsistent. Some studies supported the correlation between alphaamylase and dental caries while the others did not. For example, Scannapieco et al [15] reported that alpha-amylase can promote catalyzing the dietary starch hydrolysis by binding on the surface of cariogenic bacteria. Bacterial plaques containing amylase-binding bacteria may concentrate salivary alpha-amylase within the plaque matrix to provide more glucose from dietary starch in proximity to the tooth surface. Such plaques may play an important cariogenic role in the presence of starch-containing foods.
Liang et al [14] indicated that the composition of salivary alpha-amylase isoenzymes are related to the occurrence of dental caries. Juan et al. [13] revealed a considerable difference between the level of salivary alpha-amylase between cariesfree and caries active subjects and concluded that there was relationship between salivary alpha-amylase and dental caries. On the other hand, de Farias et al. [6] did not confirm the relationship between alpha-amylase and dental caries. They reported that children with ECC had significantly higher levels of total salivary $\operatorname{IgA}$ and IgG than children without ECC. However, the mean values of amylase activity and total IgM were similar between the groups. One reason that may explain the discrepancy between the results is that human saliva is composed of water and several electrolytes, mucus, glycoproteins, enzymes, and antibacterial compounds such as secretory $\operatorname{IgA}$ and lysozyme. In such situation, assessing the effect of a few components while ignoring the others may lead to different results due to confounding effect of the other components.

This study had a few limitations. Firstly, there are several predisposing factors for dental caries. We tried as much as possible to increase the similarity between the two groups by matching on oral hygiene and food habits in order to reduce the confounding effect of the predisposing factors. However, residual confounding effect might have distorted the results. Secondly, we indicated that emergency treatment of dental caries could increase the level of salivary alpha-amylase. However, it was not clear whether dental caries had reduced the level of alpha-amylase or reduction in alpha-amylase resulted in ECC. In other words, we could not firmly establish the proper temporal sequence between the two variables. Nonetheless, since level of alpha-amylase increased after treatment but did not reach the level of alpha-amylase seen in the ECC-free children, it seems that reduction in alpha-amylase level was probably prior to dental caries, although dental caries might exacerbate the reduction in salivary alpha-amylase. Despite the limitations, the present study had some advantages compared to previous studies. The sample size was large enough to minimize the possibility of random error. Furthermore, the study groups were as similar as possible to reduce the confounding effect of other covariates. 


\section{CONCLUSION}

It can be concluded that low levels of alphaamylase may promote early childhood caries. On the other hand, dental caries may subsequently reduce the level of salivary alpha-amylase. This vicious cycle may promote and then accelerate caries formation among susceptible people with low level of salivary alpha-amylase.

\section{ACKNOWLEDGMENTS}

We would like to thank the Vice-Chancellor of Education as well as the Vice-Chancellor of Research and Technology, Hamadan University of Medical Sciences, who supported this study.

\section{CONFLICT OF INTEREST STATEMENT}

The authors declare that they have no conflicts of interest.

\section{FUNDING}

This article was part of the DDS thesis which was funded by Hamadan University of Medical Sciences.

\section{REFERENCES}

1. Hirsch GB, Edelstein BL, Frosh M, Anselmo T. A simulation model for designing effective interventions in early childhood caries. Prev Chronic Dis. 2012;9:E66. Epub 2012 Mar 1

2. Southward LH, Eklund NP, Mosca NG, Curtis DK, Silberman SL, Lane C. Helath policy brief: children's oral health in Mississippi: addressing a silent epidemic CDC; 2003; [Internet]. Mississippi: Mississippi Health Policy Research Center [updated 2012] Available from: www.cdc.gov/ OralHealth/publications/library/burdenbook/pdfs/MS_policy_Brief. pdf.

3. Askarizadeh N, Siyonat P. The prevalence and pattern of nursing caries in preschool children of Tehran. J Indian Soc Pedod Prev Dent. 2004;22(3):92-5.

4. Edelstein BL, Chinn CH. Update on disparities in oral health and access to dental care for America's children. Acad Pediatr. 2009;9(6):415-9.

5. Seow WK. Environmental, maternal, and child factors which contribute to early childhood caries: a unifying conceptual model. Int J Paediatr Dent. 2012;22(3):157-68.
6. de Farias D, Bezerra AB. Salivary antibodies, amylase and protein from children with early childhood caries. Clin Oral Invest. 2003;7:154-7.

7. Madrid C, Abarca M, Bouferrache K, Gehri M, Bodenmann P, Pop S. Carie du biberon: un caillou dans la chaussure de la sante.Rev Med Suisse. 2012;8(335):764-8.

8. Hsieh HJ, Huang ST, Tsai CC, Hsiao SY. Toothbrushing habits and risk indicators of severe early childhood caries among Aboriginal Taiwanese. Asia Pac J Public Health. 2012; Epub ahead of print.

9. Vania A, Parisella V, Capasso F, Di Tanna GL, Vestri A, Ferrari M, et al. Early Childhood Caries underweight or overweight, that is the question. Eur J Paediatr Dent. 2011;12(4):231-5.

10. Psoter WJ. Relationships of gender and socioeconomic status with dental caries and early childhood malnutrition in Haitian children. Am J Phys Anthropol. 2012;147:240-1.

11. Subramaniam P, Prashanth P. Prevalence of early childhood caries in 8 - 48 month old preschool children of Bangalore city, South India. Contemp Clin Dent. 2012;3(1):15-21.

12. Burt BA, Pai S. Sugar consumption and caries risk: a systematic review. J Dent Educ. 2001;65(10):1017-23.

13. Juan J, Tie-zhou H, Dong-fang Z. Separation of human salivary $\alpha$-amylase from caries-free and caries-active by high performance hydrophobic interaction chro-matography. Stomatology. [Internet] 2004 [cited 2012];05 Available from: http://en.cnki.com.cn/Article_en/ CJFDTOTAL-KQYX200405005.htm

14. Liang H, Wang Y, Wang Q, Ruan M-S. Hydrophobic interaction chromatography and capillary zone electrophoresis to explore the correlation between the isoenzymes of salivary a-amylase and dental caries. J Chromatogr B Biomed Sci Appl. 1999;724(2):381-8.

15. Scannapieco FA, Torres G, Levine MJ. Salivary a-amylase: role in dental plaque and caries formation. CROBM. 1993;4:301-8.

16. Gråhn E, Tenovuo J, Lehtonen OP, Eerola E, Vilja P. Antimicrobial systems of human whole saliva in relation to dental caries, cariogenic bacteria and gingival inflammation in young adults. Acta Odontol Scand. 1988;46(2):67-74.

17. Aguirre A, Levine MJ, Cohen RE. Immunochemical quantitation of alpha amylase and secretory IgA in parotid saliva from people of various ages. Arch Oral Biol. 1987;32:297-301.

18. Mellersh A, Clark A, Hafiz S. Inhibition of neisseria gonorrhoeae by normal human saliva. Br J Ven Dis. 1979;55:20-3.

19. Harris N, Garcia-Godoy F, Nathe CN. Primary preventive dentistry. 7th ed. London: Asimon and Schuster Company; 2009. 19p.

\section{Jalal Poorolajal (MD, PhD)}

(Corresponding address)

Hamadan, Iran

Postal code: 6517838695

Received: 2012 Dez 10

E-mail address: poorolajal@umsha.ac.ir

poorolajal@yahoo.com 